\title{
WHAT DRIVES PRIVATE EQUITY INVESTMENTS IN ROMANIA?
}

\author{
Precup Mihai \\ Ph.D. Student, University of Paris 1: Pantheon-Sorbonne, France, \\ Email: mihai.precup@yahoo.com
}

(Received August 2015; accepted October 2015)

\begin{abstract}
This paper aims at presenting the determinants of private equity investments in Romania over the period 2000 - 2013. Additionally, this paper presents the main highlights in terms of evolution, source of funding and activities in which the private equity funds invested during the crisis. Starting from the existing literature, this paper extends the analysis of private equity drivers to Romanian market by including variables such as: economic growth, market capitalization, interest rate, unemployment rate and public R\&D expenditure which were already tested in previous papers. In addition, this paper introduces new variables such us productivity and corruption index which we consider important factors in explaining the evolution of private equity investments in Romania.

The results of our empirical model confirmed existing hypothesis regarding the importance of some determinants such as: unemployment rate, economic growth, market capitalization and corruption. Based on our empirical results, we have pointed several strategic directions that are meant to support the development of the private equity market in Romania.
\end{abstract}

Keywords: private equity; economic growth; market capitalization; unemployment rate; corruption; private equity determinants; Romania.

\section{Introduction}

Private equity market in Romania is a young and emerging market which is also characterized by high volatilities. This paper examines the determinants which could be significant drivers for the development of private equity investments in Romania.

The authors such as Gompers and Lerner 1998, Jeng and Wells 2000, Romain and de La Potteria 2004, Félix et al. 2007 studied the determinants of venture capital investments in developed countries such as: U.S.A. or some Western European countries. The originality of this paper consists in the fact that is one of the firsts analysis of the macroeconomic determinates for private equity investments in an emerging country such as Romania. It should be noted that Romanian private equity market was representing in 2013 only $0.13 \%$ from the total private equity investments in Europe.

One could observe that during the last two decades, numerous studies which have analyzed the macroeconomic factors concentrated only on the venture capital investments, which is a subcomponent of private equity investments and 
concentrates manly on financing young firms with high growth potential. Therefore, in our empirical model we have used the determinants of private equity which were validated by the literature for venture capital such as: real GDP growth (Gompers and Lerner (1998); Romain De La Potterie (2004) and Félix et al. (2007)), market capitalization (Black and Gilson (1998) and Félix et al. (2007)), interest rate (Gompers and Lerner (1998); Romain De La Potterie (2004) and Félix et al. (2007)), unemployment rate (Félix et al. (2007)) and R\&D expenditure (Gompers and Lerner (1998) and Romain and de La Potteria (2004)).

Additionally, we have used new variables such as productivity and corruption index which we consider that might emerge important factors in explaining the evolution of private equity investments in Romania.

Based on the fact that the financing of real economy in Romania is very dependent on the traditional credits from the commercial banks, private equity investments could represent a financing alternative. Furthermore, the role of private equity is very important in the financing of companies at all stages of life, from start-up to growth investments, and it provides not only funding but also advice and support for business. Despite the importance of the private equity financing for the real economy this market represented only 48 million euros in 2013 which is far below pre-crisis levels (e.g. 156 millions in 2007).

In this paper we believe that in order to understand the drivers and the evolution of private equity investments in Romania we should concentrate on two main aspects: First, we should present the main highlights of private equity investments in Romania during the last crisis. From this point of view, we will examine the dynamics of private equity market, the economic sectors which were targeted by such investments, the funds raised and their sources. Furthermore, we will look at the proportion of private equity market on the total GDP in Romania and we will compare it with other Eastern European countries because this might be an indicator which shows that this market is an emerging one.

Second, we will identify the determinants of private equity investments in Romania by building a linear regression using the estimation method of ordinary least squares (OLS). Once we have estimated the parameters of the linear regression we will explain for each determinant the theoretical impact on the evolution of private equity investments in Europe. Additionally, we will compare our empirical results with the results validated from previous studies. Hence, we expect the attractiveness factors for private equity in Romania to be different from the drivers validated for Western European countries.

The reminder of this paper will be organized as follows: Section 2 will describe the macroeconomic variables, the technological opportunities and the institutional drivers. Section 3 will presents the main highlights in terms of evolution, source of funding and activities in which the private equity funds invested during the crisis. 
Precup, M. (2015)

What drives private equity investments in Romania?

Section 4 will present the data and the methodology employed to identify the main determinants of private equity investments evolution in Romania. Section 5 explains and compares our results with the literature and Section 6 concludes this paper and presents some recommendations for the policy makers.

\section{How does private equity worked for Romania?}

The majority of private equity investments on the Romanian market are made by non-Romanian private equity funds and Romanian funds have a limited presence. Private equity funds incorporated in Romania are very rare, as Romania does not have competitive legislation encouraging their creation. For tax reasons, Romanian private investors prefer to incorporate private equity funds in foreign jurisdictions or invest directly in existing funds.

Foreign private equity funds generally structure their investments in Romania either through local special purpose vehicles (SPVs) organized as limited liability companies or, most often, by using SPVs incorporated in tax-friendly jurisdictions (for example, Cyprus, Luxembourg or The Netherlands).

Private equity funds aim to acquire interest in funding high-growth potential companies and in the development of these companies. A particular attention is given to companies with regional expansion potential, through subsequent acquisitions. Most private equity funds primarily seek capital gains in the medium term, their life period being on average ten years.

Private equity investors are different from the traditional investors in that they are so called "hands on" and they get involved proactively in the management of the company that they invest. The private equity fund managers could provide directly their expertise to the company in order to help it to establish a development strategy or to find new acquisition targets.

Romain and de La Potterie (2004) confirmed that the private equity could represent a financing alternative for companies with growth potential which have a difficult time in finding capital. The authors showed that more the credits from the traditional commercial banks is expensive, more the managers of the companies are interested in private equity sources of funding.

The main challenge for the private equity market in Romania is the exit strategy limited opportunities. In Romania the capital market is emerging but is still well below western European markets. For this reasons the forms of exit strategy typically used by the private equity funds to divest from a successful company are either by selling the company to a strategic investor, either by secondary buyouts. In 2013, private equity funds divested from four Romanian companies as follow: one was sold to the company's management, one was subject to a secondary buyout and two were sold to another private equity house. 
In the context of the last crisis Romanian aggregate private equity market decreased by $23 \%$ compared to pre-crisis levels in 2007, with only 10 transactions being recorded in 2013. The average value of private equity transaction was 4.8 million euros.

Table 1. Private equity dynamics in Romania versus European Union average $(2007=100)$

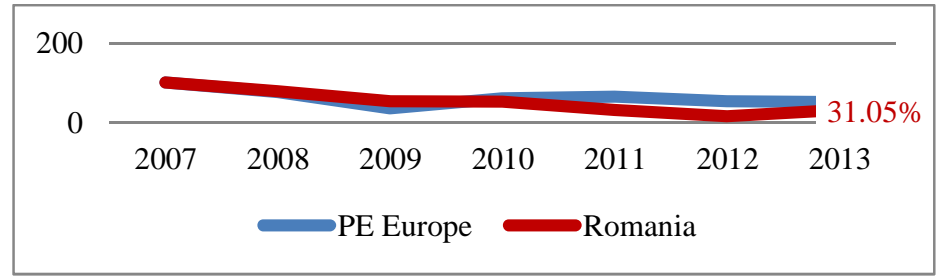

Source: the author based on the information provided by the report „European Private Equity Activity 2013”. Available: www.evca.eu. Consulted in September 2014.

It should be noted that Europe is still in the grip of a deep investment crisis, particularly in non-EA emerging economies. Table 1 show that private equity investments didn't do any exception. Even though overall economic growth has recovered in Romania and throughout most of the non - Euro Area economies, overall private equity investments in those countries are still well below 2007 levels.

Generally, the private equity investment drop in Romania was greater than the EU average. This was primarily driven by the financial crisis which has triggered a sudden interruption of private capital flows coming from the developed European economies to the Romanian economy.

An additional factor was the deleveraging process in the banking sector which has begun in 2011 after the Vienna I Agreement expiration, leading to a substantial reduction of financial resources available to the non - Euro Area economies, such as Romania.

Table 2 shows that Poland Romania and Hungary are the main private equity markets in Eastern Europe. This is also in relation with the size of real economy, expressed in GDP units. Hence, the private equity investments share in the total GDP of these countries remain very modest compared with other Western European countries which makes us believe that those markets are still emerging ones.

Over the period 2000 - 2013, the European average share for private equity investments in GDP was $0.19 \%$ which was slightly above the share indicated in 
Precup, M. (2015)

What drives private equity investments in Romania?

Eastern European countries. Additionally, in some European developed countries with a solid banking sector and with a certain openness of the management of nonlisted companies to new sources of funding, such as Britain, the investment share of "private equity" in GDP was just $0.8 \%$ of GDP at the end of 2012.

Table 2. Private equity investments share in GDP for Eastern European countries over 200 - 2013 (\% GDP)

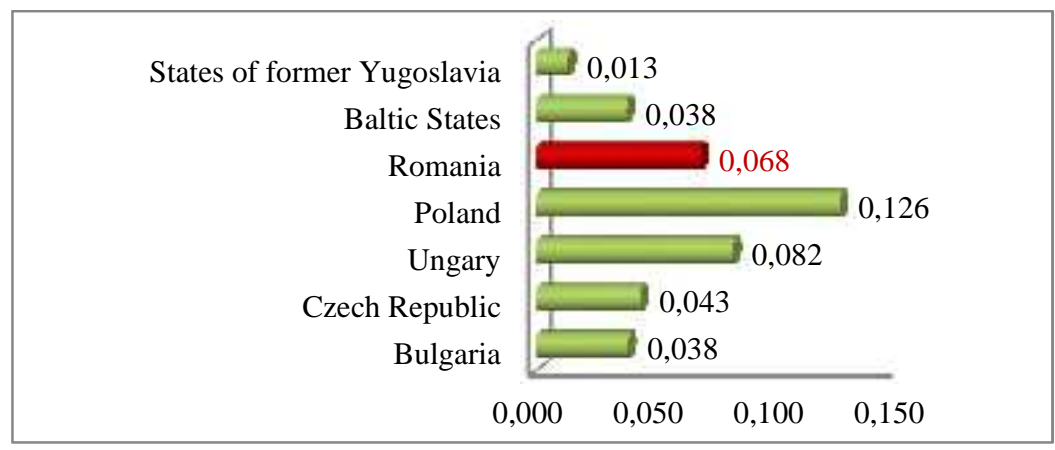

Source: the author based on the information provided by the report „European Private Equity Activity 2013”. Available: www.evca.eu. Consulted in September 2014.

Table 3. Economic activities share in total private equity investments in Romania (2007 versus 2013)

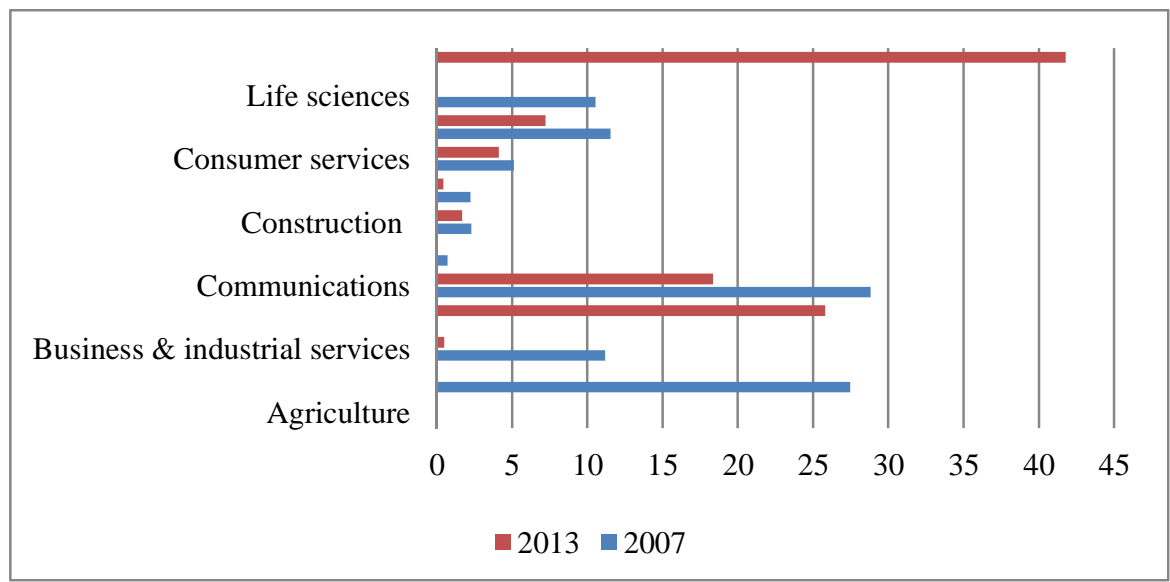

Source: the author based on the information provided by the report „European Private Equity Activity 2013”. Available: www.evca.eu. Consulted in September 2014. 
Between 2007 and 2013, Romania attracted 861 million euros of private equity investment, reaching one of the heights levels of private equity among European emerging countries. Table 3 shows that private equity investors' preferences changed during this period in Romania. Manly because of the last crisis, local private equity funds oriented their investments to sectors such as transportation or industry of chemicals and materials which represented $68 \%$ from the total private equity investments in Romania.

Hence, the communication sector remains one of the main destinations of private equity investments in Romania. Despite the crisis, the share of private equity investments in communication represented $18 \%$ from total private equity investments in Romania in 2013. However, this represents a decrease of 38\% compared to pre-crisis levels.

One could observe that the agriculture sector which is one of the main pillars of Romanian economy didn't benefit of any private equity investment during the period that we study. This might be explained by the fact that the managers didn't open the capital of their companies to private equity investors.

Table 4. Source of funding share in total private equity new funds raised $2007-2013$

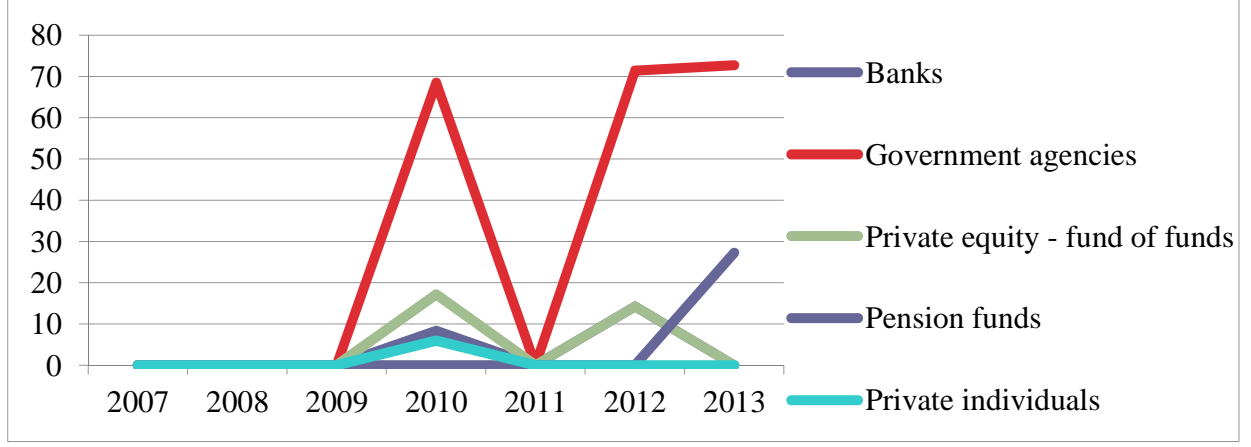

Source: the author based on the information provided by the report „European Private Equity Activity 2013”. Available: www.evca.eu. Consulted in September 2014.

The majority of private equity funds raised for Romanian economy are made by non-Romanian entities. Table 4 shows that most of the funding sources are coming from government agencies such as: the European Investment Fund (EIF), the European Bank for Reconstruction and Development (EBRD) or the International Finance Corporation (IFC). One could notice that the government agencies became a very important source of funding for private equity activities in Romania, particularly during the crisis in order to compensate the investment outflow from 
the Eastern European markets such as Romania. In 2013, the share of government agencies in the total source of funding for private equity in Romania reached $73 \%$. During the last years, one could observe a strong increase in the interest of pension funds in the opportunities offered by the Romanian private equity market. In 2013, the share of new funds coming from the pension funds reached $23 \%$ from the total private equity funds raised for Romanian market.

Despite the important role of the banking sector in financing the real economy in Romania, this remains marginal in financing the private equity industry. Other institution investor in the private equity market is represented by non-residential private equity funds which are providing resources to local private equity funds. So called, funds of funds operations represented $14 \%$ from the total new funds raised in 2012.

\section{Literature review}

The most relevant studies for this paper are the ones which are led by the following authors: Gompers and Lerner (1998), Jeng and Wells (2000), Romain and de La Potterie (2004) and Félix et al. (2007). To examine the determinants of private equity in Romania, first we will start by reviewing the dependent variables which were already confirmed by the literature and second we will introduce new dependent variables which we consider important for Romanian market.

Macroeconomics Determinants of Private Equity

- Economic growth: The first macroeconomic determinant of private equity is the economic growth expressed as Gross Domestic Product in real terms.

Gompers and Lerner (1998), Romanin and de La Potterie (2004), respectively Félix et al. (2007) validated a positive impact on the private equity.

In this paper we will expect a positive correlation between the economic growth and private equity investments in Romanian.

- The interest rate: This variable represents the annual real interest rate which is characterized by high volatilities in emerging countries such as Romania.

Romain and de La Potterie (2004) studied the impact of the long term interest rate on the evolution of private equity in 16 OECD countries. The authors confirmed a positive relation between both variables.

Gompers and Lerner (1998) concentrated on analyzing the impact of the short-term interest rate on the evolution of U.S. venture capital. The short-term interest rate expressed as the return on U.S. treasury bills proved to have a negative impact on venture capital.

In this paper we are analyzing the relation between the long term interest and the Romanian private equity, so we will expect to confirm a positive relation between both variables. 
- The unemployment rate: This variable represents the total unemployment in percentage total labor force.

Félix et al. (2007) proved that unemployment rate has a negative impact on the evolution of private equity. Félix et al. (2007) studied the dynamic of private equity market in 23 European countries over $1992-2003$ and their paper is one of the few which has exclusively concentrated on the European private equity market. Our paper will test also a negative relation between the evolution of private equity investments in Romania and the unemployment rate.

- Stock market capitalization: This variable equals to the value of listed domestic companies' shares on Romanian's major stock exchange market.

Authors such as Jeng and Wells (2000) considered the stock market and the number of IPO are the main drivers for the private equity investments. The authors affirmed that a dynamic stock market could provide interesting opportunities to divest and could represent an important motivation factor for the private equity investors.

Félix et al. (2007) also validate a positive relation between the market capitalization and the evolution of private equity in Europe.

In our empirical model we will expect to prove that stock market capitalization affects positively the private equity investments in Romania.

- Productivity: is a new variable which we introduce in our empirical model because we consider this as an important motivation factor for the private equity funds to invest in a Romanian company. In this paper the variable productivity is considered as the total value added generated in one year per employee.

This variable was never studied by any previous author and we suppose that our empirical model will show a positive relation between the productivity and the evolution of private equity investments in Romania.

\section{Technological Opportunities}

- Research and Development expenditure: This variable reflects the total value of public R\&D expenditure as a percent of GDP.

Gompers and Lerner (1998) showed that an increase in Research and Development expenditure was followed by an increase in technological opportunities and in the '90s, this had a positive impact on the demand and supply of venture capital funds in U.S.

Romain and de La Potterie (2004) also confirmed a positive impact of technological opportunities on the evolution of venture capital investments.

Our hypothesis is that R\&D expenditure should have a positive impact on the private equity dynamic in Romania. 
Precup, M. (2015)

What drives private equity investments in Romania?

\section{Institutional drivers}

- Corruption: This variable will coincide with the corruption index provided by the organization Transparency International and reflects the perception of corruption in the business environment, including levels of governmental legal, juridical and administrative corruption.

Cherif and Gasdar (2009) were by the only authors which have studied the impact of corruption on the evolution of venture capital in U.S. For these authors, the corruption was significant variable and had a negative influence on the venture capital dynamics.

In our paper we will expect a negative relation between the corruption index and the private equity evolution in Romania.

\section{Data and research methodology}

Data

For the empirical analysis, we use data from Romania over the period of 2000 2013. Our data refers to private equity investments which are transactions where a private-equity firm buys majority control of an existing or mature firm with a high potential of growth. This type of investments target only unlisted companies at all stages of life, from young or emerging companies to mature firms.

The data is collected from the annual reports published by EVCA ("European Venture Capital Association") and by Thomson and Reuters. It should be noted that the private equity market is very young in Eastern European countries such as Romania and the data availability is quite limited.

The following variables: annual real GDP growth rate, market capitalization, interest rate, unemployment rate, $\mathrm{R} \& \mathrm{D}$ expenditure, corruption and productivity per employee were collected from the annual reports provided by Eurostat.

The exception is the corruption where we have used the database of transparency.org. In our empirical model the corruption is ranking from 1 to 100. Hence one could notice that corruption index for the Romania during 2000 -2013 is on the lower part of the ranking and below the European average.

Research Methodology

This paper will work to validate a significant correlation between the dependent variables and the evolution of private equity investments in Romania. For this reason, our empirical model will consist in validating liner retrogression such as the following one:

$$
\begin{aligned}
& \text { InvPE } E_{i t}=\beta_{0}+\beta_{1} \text { VarGDP }_{t}+\beta_{2} \text { Unemployment }_{t}+\beta_{3} \text { MarketCapitalization }_{t}+\beta_{4} R \& D_{t} \\
& +\beta_{5} \text { Interest }_{t}+\beta_{6} \text { Productivity }_{t}+\beta_{7} \text { Corruption }_{t} \\
& \mathrm{t}=1, \ldots 13
\end{aligned}
$$


InvPE - private equity investments

$\operatorname{VarGDP}$ - economic growth expressed as the variation of real GDP

Unemployment-unemployed people as percentage of total labor force.

Interest - the annual real interest rate

$R \& D-$ public R\&D expenditure

Market Capitalization - the value of listed domestic companies' shares on

Romanian's major stock exchange market.

Corruption - corruption index as provided by cpi.transparency.org

Productivity - the total value added generated in one year per employee.

Once the linear regression validated we will test its robustness by carried out tests in order to study the presence of heteroscedasticity and to identify a possible autocorrelation of its error terms.

\section{Empirical results}

In our empirical analysis we have worked to validate a relation, statistically significant, between the evolution of private equity in Romania during 2000 - 2013 and the following dependent variables: economic growth, market capitalization, interest rate, unemployment and public $\mathrm{R} \& \mathrm{D}$ expenditure, as well as productivity and corruption index.

Table 5 shows the most statistically significant regression which was validated using Student's t-test in EVIEWS. This test helped us to eliminate the variables step by step in descending order of their significance. Finally, we have chosen the linear regression with the most significant variables for the dynamic of private equity in Romania and the highest R-squared and R-squared adjusted.

Table 5. Empirical results with OLS estimation for the Private Equity variable

\begin{tabular}{ll} 
Economic growth & $\begin{array}{l}112978.9 \\
(1.216)\end{array}$ \\
Unemployment & -4063181 \\
& $(-6.467)^{\mathrm{a}}$ \\
Market capitalization & 2.62 \\
& $(6.782)^{\mathrm{a}}$ \\
Corruption & -3351.44 \\
& $(-1.956)^{\mathrm{b}}$ \\
Productivity & 2805.5 \\
& $(1.165)$ \\
Adjusted R-squared & 0.936 \\
\hline
\end{tabular}

Source: the author. In the table it is presented the results of the OLS estimation. In parentheses it is presented the values of the t-statistics for each variable. The t-statistics values are significant at the following levels: ${ }^{\text {a }}$ significance at $5 \%$; ${ }^{\text {b }}$ significance at $10 \%$; and, ${ }^{\mathrm{c}}$ significance at $20 \%$ 
As shown by the Table 5, the dependent variables validated by our empirical model explain almost $93 \%$ of the evolution of private equity in Romania.

The empirical model which was selected during our simulations considered the following variables as having the most relevant impact on the private equity market in Romania: economic growth, unemployment, stock market capitalization, productivity and corruption. The retrogression that we accepted as most significant is the following:

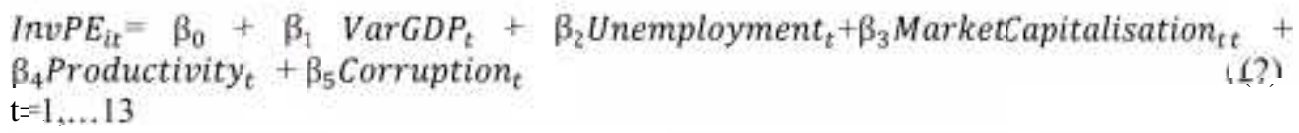

The linear regression with the coefficients validated as significant:

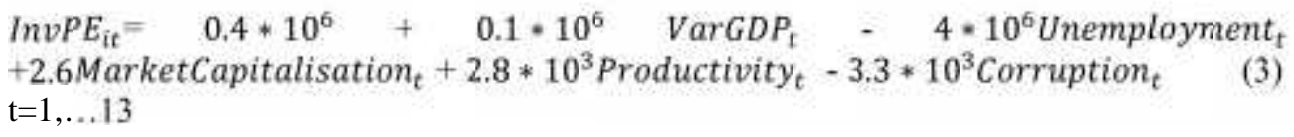

Hence, in the following section we will run some robustness test in order to see if this estimation is optimal for our empirical model.

\section{Heteroscedasticity}

In this section we will study the heteroscedasticity under to aspects: i) we do a graphic analysis of the distribution of the error terms and ii) we will run econometric tests in order to understand the distribution of the error terms for our empirical model.

Homoscedasticity means that the variance of the error term is constant $\left(\mathrm{V}\left(\varepsilon_{i}\right)=\sigma^{2}\right.$ for all $i$ ). If the error terms do not have constant variance, they are said to be heteroscedasticity.

Scatter diagram of squared residuals is useful to examine the model's residual visually, before actually carrying out any formal tests of heteroscedasticity. The graphs in Table 6 shows that the squared estimated residuals are distributed randomly which makes us believe that there is no homoscedasticity.

Econometrically, we have applied the test of White (1980) which assumes that the regression is characterized by homoscedasticity $\left(\mathrm{N}^{*} \mathrm{R}^{2} \approx \chi^{2}, \quad H \quad{ }_{0}=\right.$ homoscedasticity).

The results of the test of White (1980) show that the null hypothesis is accepted: $\mathrm{N}^{*} \mathrm{R}^{2}(6,558)<\chi^{2}$ with 5 degrees of freedom (9.488). This means that our regression doesn't have any problem of heteroscedasticity and the variance of the squared estimated residuals is constant $\mathrm{H}_{0}=\operatorname{var}\left(\mathrm{u}_{1}\right)=\operatorname{var}\left(\mathrm{u}_{2}\right)=\ldots=\operatorname{var}\left(\mathrm{u}_{\mathrm{T}}\right)=$ cte. 
Precup, M. (2015)

What drives private equity investments in Romania?

Finally, accepting the null hypothesis, $H_{0}=$ homoscedasticity, we can conclude that our OLS estimation is a linear, unbiased and efficient estimation.

Table 6. Heteroscedasticity graphic representation
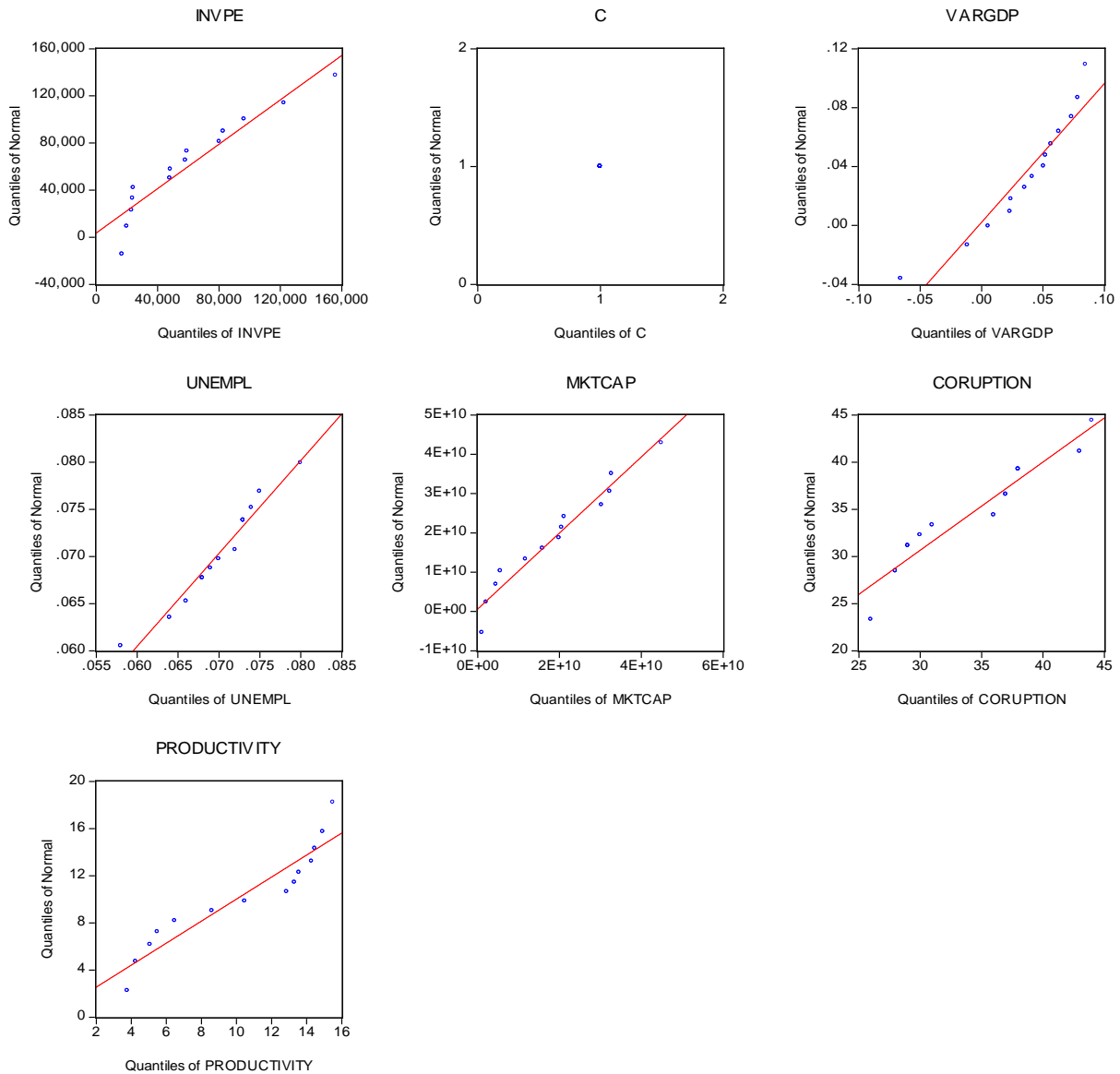

Source: the author's simulation in EVIEWS.

\section{Autocorrelation}

In this paper we used Durbin-Watson test in order to detect the presence of autocorrelation in the error terms from our linear regression.

If $e_{t}$ is the error term associated with the observation at time $\mathrm{t}$, then the test statistic is: 
What drives private equity investments in Romania?

$$
D W=\frac{\sum\left(e_{t}-e_{t-1}\right)^{2}}{\sum e_{t}^{2}} \approx 2 \cdot\left(1-\rho_{1}\right)
$$

The null hypothesis tested is Ho: $\rho=0$ and if this hypothesis is accepted then we can conclude that there is an autocorrelation of order 1 between residuals in $t$ and $t-1$.

In our linear regression, Durbin-Watson statistic is 1.595 , at a level of significance of 0.05 and $k^{\mathrm{I}}=4$. With $\mathrm{d}=0,39$, the lower critical value and $\mathrm{d} v=1,96$, the upper critical value, we conclude that the Durbin-Watson test is inconclusive because $\mathrm{d} \in$ $\left[\mathrm{d}_{1}, \mathrm{du}\right]$. In this case, Durbin-Watson test cannot provide statistical evidence that the error terms are autocorrelated.

It should be noted that Durbin-Watson test is only possible for testing the possibility of a first-order autoregressive model $(\mathrm{AR}(1))$ and in the following analysis we will use a more general test called LM which is statistically more powerful than Durbin-Watson statistic.

LM test allows us to study the autocorrelation of order $\mathrm{n}$ and its null hypothesis states that there is no serial correlation of any order up to $\mathrm{p}$ :

$e_{\mathrm{t}}=f\left(e_{\mathrm{t}-1}, e_{\mathrm{t}-2}, \ldots, e_{\mathrm{t}-\mathrm{p}}\right)$

We consider a linear regression where the error terms might follow an $\operatorname{AR}(\mathrm{p})$ autoregressive scheme, as follows:

$e_{t}=\alpha_{1}+\alpha_{2} \cdot x_{2 t}+\gamma_{1} \cdot e_{t-1}+\gamma_{2} \cdot e_{t: 2}+\ldots+y_{p} \cdot e_{t, p}+\varepsilon_{t}$

Where the null hypothesis of no serial correlation of any order up to $\mathrm{p}$ is the following:

$\mathrm{H}_{0}: \gamma_{1}=\gamma_{2}=\ldots=\gamma_{r}=\mathrm{u}$

LM statistic is characterized by the following distribution:

$\mathrm{LM}=\mathrm{T} \cdot \mathrm{R}^{2} \mathrm{AUX} \approx \chi^{2} \mathrm{p}$

Where $\mathbf{p}$ is the number of degrees of freedom and the number of lags of the error term, respectively $\mathbf{T}$ is the number of observations in the basic series. In our estimation model we will introduce 6 lags of the error term.

LM statistic with 6 legs of the error term is higher than the $\chi^{2}$ with 6 freedom degrees which means that we might have an autocorrelation of order 2 . Additionally, Student's t-test confirms that the coefficient of the $2^{\text {nd }}$ leg of the error term is significant.

Furthermore, in table 7 , the analysis of correlograms also confirms a possible autocorrelation of order 2 .

We run a second estimation in order to test the significance of a second-order autoregressive model $(\mathrm{AR}(2))$ for our regression errors. LM test confirmed that there is no serial correlation of any order up to 2 lags of the error term $(p=2)$. In 
Precup, M. (2015)

What drives private equity investments in Romania?

conclusion, second-order autoregressive model (AR(2)) is the optimum estimation. The study of the correlograms in table 8 also confirms that the autocorrelation of order 2 was corrected.

Table 7. Correlogram of our regression basic model

\begin{tabular}{|c|c|c|c|c|c|c|c|c|c|c|c|}
\hline \multicolumn{3}{|c|}{ Autocorrelation } & \multicolumn{4}{|c|}{ Partial Correlation } & \multirow{2}{*}{\multicolumn{2}{|c|}{$\frac{A C}{0.195}$}} & \multirow{2}{*}{$\frac{\text { PAC }}{0.195}$} & \multirow{2}{*}{$\frac{\text { Q-Stat }}{0.6161}$} & \multirow{2}{*}{$\begin{array}{l}\text { Prob } \\
0.432\end{array}$} \\
\hline 1 & り & ' & ' & & コ & 1 & & & & & \\
\hline E & & 1 & ᄃ & & & 1 & 2 & -0.606 & -0.669 & 7.1185 & 0.028 \\
\hline 15 & & 1 & 1 & 만 & & 1 & 3 & -0.424 & -0.182 & 10.621 & 0.014 \\
\hline 1 & 昏 & 1 & 1 & 름 & & 1 & 4 & 0.159 & -0.172 & 11.169 & 0.025 \\
\hline I & $\square$ & 1 & , & 口 & & 1 & 5 & 0.274 & -0.224 & 12.999 & 0.023 \\
\hline 1 & 㞋 & 1 & 1 & & コ & 1 & 6 & 0.197 & 0.236 & 14.081 & 0.029 \\
\hline I & & 1 & 1 & 맘 & & 1 & 7 & -0.121 & -0.239 & 14.557 & 0.042 \\
\hline$\theta$ & & 1 & ' & & & 1 & 8 & -0.268 & 0.033 & 17.358 & 0.027 \\
\hline 1 & & I & ' & 다 & & 1 & 9 & -0.101 & -0.104 & 17.858 & 0.037 \\
\hline 1 & b & 1 & 1 & 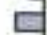 & & 1 & 10 & 0.129 & -0.207 & 18.947 & 0.041 \\
\hline 1 & 5 & 1 & I & 正 & & 1 & 11 & 0.066 & -0.160 & 19.377 & 0.055 \\
\hline I & & 1 & , & 是 & & i & 12 & -0.001 & -0.179 & 19.378 & 0.080 \\
\hline
\end{tabular}

Source: the author's simulation in EVIEWS.

Table 8. Correlogram of second-order autoregressive model (AR(2))

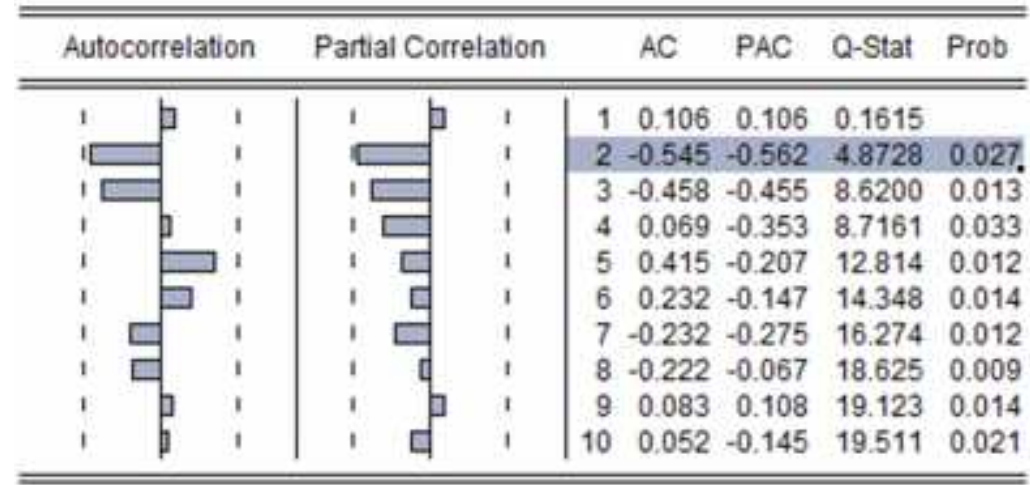

Source: the author's simulation in EVIEWS.

The final estimation which was validated as significant after the treatment of of $\mathrm{tt}$ autocorrelation of second order is:

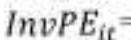
$0.3+10^{6}$
$0.12 * 10^{6}$
$\operatorname{VarGDP} P_{t}$
$4 * 10^{6}$ Unemmpmement
+2.5 MarketCapitalisation $_{t}+3 * 10^{3}$ Productivity $_{t}-3.5 * 10^{3}$ Corruption $_{t} \cdot t-1 \varepsilon_{t} \varepsilon_{t}(9$ $\mathrm{t}=1, \ldots 13$ 
Table 9. Empirical results of OLS estimation of the second-order autoregressive model $(A R(2))$

\begin{tabular}{ll} 
Economic growth & $\begin{array}{l}120746 \\
(1.993)^{\mathrm{b}}\end{array}$ \\
Unemployment & -4060667 \\
& $(-10.044)^{\mathrm{a}}$ \\
Market capitalization & 2.56 \\
& $(11.554)^{\mathrm{a}}$ \\
Corruption & -3572.301 \\
& $(-2.737)^{\mathrm{b}}$ \\
Productivity & 3038.434 \\
& $(1.724)^{\mathrm{c}}$ \\
AR (2) & -0.672935 \\
& $(-2.079)^{\mathrm{c}}$ \\
Adjusted R-squared & 0.976 \\
\hline
\end{tabular}

Source: the author. In the table it is presented the results of the OLS estimation. In parentheses it is presented the values of the t-statistics for each variable. The t-statistics values are significant at the following levels: ${ }^{\text {a }}$ significance at $5 \%$; ${ }^{\text {b }}$ significance at $10 \%$; and, ${ }^{\mathrm{c}}$ significance at $20 \%$.

It should be highlighted that the dependent variables validated by the above mentioned estimation explain almost $97 \%$ from the evolution of private equity in Romania. However, one aspect should be noted that only, the productivity, the dependent variable which we introduce for the first time in this model, was not validated as having a statistically significant impact on the private equity market in Romania.

Our results showed that the economic growth was statistically significant only for a level of significance of $10 \%$. Student-t statistic confirmed with a probability of $90 \%$ that the economic growth had a statistically significant and positive impact on the evolution of private equity market in Romania. This is in line with the conclusion of authors such as Gompers and Lerner (1998b) and Romanin and La Potterie (2004). However, one should mention that there are also authors such as Jeng and Wells (200) and Marti and Balboa (2001) which showed that the economic growth was not statistically significant for the venture capital market in U.S.

For the market capitalization, our results showed that the Student-t statistic (11.554) is outside the margins of confidence interval $(-2.178 ; 2.178)$ for a level of significance of $5 \%$. In this case we can confirm with a probability of $95 \%$ that the stock market capitalization is statistically significant and impacts positively the evolution of private equity market in Romania. This is in line with the conclusion 
of the authors such as Jeng and Wells (2000) or Félix et al. (2007). Additionally it should be highlighted that according to our results the stock market capitalization has a lower economically relevance since the coefficient is very low compared to the coefficients of other dependent variables.

With respect to the unemployment, our results confirmed the conclusion of Félix et al. (2007) and showed a statistically significant and negative relation between this variable and the private equity dynamics in Romania. Table 5 showed that the unemployment was confirmed statistically significant for a probability of $95 \%$ because the Student-t statistic (-10.044) was outside the margins of confidence interval $(-2.178 ; 2.178)$ for a level of significance of $5 \%$.

The corruption proved to be an institutional determinant factor for private equity investments in Romania. However, the corruption was confirmed as statistically significant only for a level of significance of $10 \%$ because the Student-t statistic (2.737) was outside the margins of confidence interval $(-1.782 ; 1.782)$ for a level of significance of $5 \%$. The corruption had a negative impact for private equity investments in Romania over the period 2000-2013.

The last macroeconomic variables: long term interest rate and $R \& D$ expenditure were eliminated step by step in descending order of their significance before choosing a linear regression with high R-squared adjusted.

\section{Conclusion}

The objective of this research was to identify the drivers of the Romanian private equity market. To this end, we have estimated an liner retrogression between the private equity investments and the dependent variables. Additionally, checked the robustness of the linear regression and we carried out tests such as White (1980) in order to study the presence of heteroscedasticity, respectively Durbin-Watson (1951) and Breusch-Godfrey Serial Correlation LM (1978) to identify the autocorrelation.

This paper identifies the determinants of private equity investments in Romania during the period from 1996 to 2006. In our empirical model we have introduce various variables which includes many of the determinants already tested in the literature such macroeconomic variables (economic growth, interest rate, unemployment rate, stock market capitalization) and variables which reflect technological opportunities (research and development expenditure). In addition, we have tested if the productivity and the institutional quality variables such as corruption index are important drivers for the private equity investments in Romania.

The results show that the private equity market is manly affected by the following macroeconomic determinants: unemployment (-), stock market capitalization $(+)$ 
and the economic growth (+). Additionally, the corruption had negative impact on the evolution of private equity investments in Romania.

One important conclusion for the policy makers in Romania is that in order to develop the private equity market, actions should be initiated to improve the public institution transparency.

Another important conclusion for the policy makers is that in order for Romania to remain competitive for the private equity investments, specific structural reforms should be initiated to encourage the economic growth and to reduce the unemployment. Romanian capital market, which reflects the real economy, should attract new issuers such as state own companies and should promote stock exchange among the large audience.

\section{References}

1. Black, B. and Gilson, R. (1998). „Venture Capital and the Structure of Capital Markets: Bank versus Capital Markets", Journal of Financial Economics, p. 243277.

2. Bourbonnais, R. (2000) „Econométrie”, DUNOD, p.201 - 222.

3. Breusch T. S. (1978), "Testing for Autocorrelation in Dynamic Linear Models". Australian Economic Papers, p.334-355.

4. Cherif, M. (2009) „Public institutions and venture capital in Europe: a crosscountry panel data analysis", Reims University Working Paper.

5. Cherif M. and Gasdar K. (2009), „What drives venture capital in Europe? A cross-country panel data analysis", International Journal of Public Management Performance, p.112-130.

6. Durbin J. and Watson G. S. (1950), „Testing for Serial Correlation in Least Squares Regression, I", Biometrika 37, p.409-428.

7. Durbin J. and Watson G. S. (1951), „Testing for Serial Correlation in Least Squares Regression, II", Biometrika 38, p.159-179.

8. Elisabete G. et al. (2007) „The Determinants of Venture Capital in Europe Evidence Across Countries", Published by CEFAGE, p.3-32.

9. EVCA (2014), „European Private Equity Activity 2013” Report. Available: www.evca.eu. Consulted in September 2014.

10. Felix E., Gulamhussen M. A. and Pires C.P., (2007), „The determinants of venture capital in Europe evidence across countries", Published by CEFAGE UE, p.11-25.

11. Godfrey, L. G. (1978), „Testing Against General Autoregressive and Moving Average Error Models when the Regressors Include Lagged Dependent Variables", Econometrica, p.1293-1301. 
12. Gompers P. \& Lerner J., (1990), „The Determinants of Corporate Venture Capital Success: Organizational Structure, Incentives, and Complementarities", NBER Working Paper, no 6725.

13. Gompers, Paul A. (1996) „Grandstanding in the Venture Capital Industry.” Journal of Financial Economics, p. 133-156.

14. Gompers P. \& Lerner J., (1998), „What Drives Venture Capital Fundraising?”, Brooking Papers on Economic Activity, Macroeconomics, p. 149-192.

15. Gompers P. \& Lerner J. (2001), „The Venture Capital Revolution”, Journal of Economic Perspectives, p.145-168.

16. Gompers P., Lerner J., Kovner A. and Scharfstein D. (2005) „The Venture Capital Revolution", Journal of Economic Perspectives, p.145-168.

17. Gompers, Paul A., Victoria Ivashina, and Joris Van Gool. (2013) „,Note on LBO Capital Structure.” Harvard Business School Module Note, p.214-239.

18. Hurlin C. (2012) „L’Econométrie des Données de Panel - Modéles Linéares Simples", cole Doctorale Edocif.

19. Jagwani S., (2000), „Supply and demand of venture capital in the US”, The Park Place Economist, p. 90-98.

20. Jeng L. \& Wells P., (2000), „The Determinants of Venture Capital Funding : Evidence Across Countries", Journal of Corporate Finance, p. 241-289.

21. Kortum S. \& Lerner J., (2000), „Assessing the Contribution of Venture Capital to Innovation", Rand Journal of Economics, p. 674-692

22. Marti and Balboa (2001), „The determinants of private equity in fundraising western Europe", Working paper.

23. Romain A. \& de la Potterie B.V.P., (2004), „The determinants of venture capital : a panel data analysis of 16 OECD countries", Published by Research Institute in Management Science, p.10 - 35.

24. White H. (1980), „A Heteroskedasticity-Consistent Covariance Matrix Estimator and a Direct Test for Heteroskedasticity", Econometrica 48, p.817-838. 